August 11, 2015. NOTE: This is the accepted version of this article, pre-copyediting. The cleaned-up article has been published in Social Studies of Science online before print June 23, 2015, doi: 10.1177/0306312715589220. In case you want to cite/reference, please refer to the online/published version.

\title{
The Pasteurization of Marie Curie: A (meta)biographical experiment
}

\section{Eva Hemmungs Wirtén,}

Department of Social Change and Culture, Linköping University, Norrköping, Sweden

\begin{abstract}
Biographies of scientists occupy a liminal space, highly popular with general readers but questioned in academia. Nonetheless, in recent years historians of science have not only embraced the genre with more enthusiasm and less guilt, they have also turned to the metabiography in order to renew the study and story of scientists' roles. This essay focuses on Marie Curie, the world's most famous female scientist, in order to unpack some of the theoretical and methodological claims of the science biography, and especially to address the sexing mechanisms at play in the construction of the biographical subject. Pierre Curie (1923), her biography of her dead husband Pierre, paid tribute to her dead husband and collaborator, but also allowed Curie a legitimate outlet to construct her own persona and legacy. Categories such as personhood, person and persona are not only central to the biography genre but also are essential to the sense of self and self-fashioning of scientists. Looking at how Marie Curie negotiated these categories in Pierre Curie not only gives new insight into Curie's selffashioning strategies, but may also shed some light on the more general analytical lacunae of the science biography.
\end{abstract}

\section{Keywords}

metabiography, Marie Curie, sexing, personhood, science biography

\section{Corresponding author:}

Eva Hemmungs Wirtén, Department of Social Change and Culture, Linköping University, 60174 Norrköping, Sweden

Email: eva.hemmungs.wirten@liu.se 


\section{Introduction}

Nothing in the title of Bruno Latour's book Les Microbes: Guerre et Paix (1984) suggests that it has anything to do with Louis Pasteur. Nor, for that matter, does it necessarily implicate Leo Tolstoy. Separately or in combination, the three words microbes, war and peace call up neither French scientist nor Russian novelist. However, it takes the reader only a few sentences to understand that Guerre et Paix refers to Tolstoy's 1869 novel War and Peace and a few more passages to realize that Tolstoy's description of the battle of Tarutino, where the Russian general Kutuzov defeated Napoleon, offers an analogy for Louis Pasteur's victory over the microbes. Kutuzov's decisions turn out to be Pasteur's. Both lead men into battle, both defeat opposing armies. Whereas Kutuzov must outflank and outwit the French, Pasteur must outflank and outwit nation-less microbes. This is Latour at his most eloquent; an elegant opening of a work that one reviewer called a 'sprawling, contradictory, but fascinating hodgepodge' (Rheingold, 1991: 178).

A few years later, when the book entered wider circulation in English translation by Alan Sheridan and John Law, it was with a very different title. Harvard University Press' choice of The Pasteurization of France (1988) retained an overall sense of conquest, but framed as a more benevolent engagement than the French original. As Gerard Genette pointed out in Seuils (1987), the paratext of titles and covers, acknowledgements and indexes - the often ignored elements of a book that constitute its textual threshold - produce not only new materialities but also enable new readings of, as in this case, a scientist like Pasteur.

Primarily, Pasteurization refers to the process of heating and immediately cooling a food to reduce the number of pathogens it contains. But in combination with of France, the term moves into new territory. Now, Pasteurization becomes less a matter of the chemical process proper, and more about the successful enrollment of 
an entire nation in an eponymic scientific project. Defeating anthrax and normalizing sterilization in agriculture are the kind of achievements for which Pasteur is regarded as being one of the 'greatest Frenchmen of all times' (Le Nouvel Observateur, 2006). Inspired less by the presence and more by the absence of Pasteur in The Pasteurization of France, I want to suggest an alternative use of the term. I use Pasteurization to denote the range of possibilities available in the construction and deconstruction of biographical subjects. My modest suggestion is that such a reading of Pasteurization offers a 'serious playfulness' that can help us see and think differently about the rhetorical devices through which scientists are made and unmade. For a book that never claimed to be a biography, The Pasteurization of France still manages to say quite a lot about the limits and possibilities of the biography genre. The choices for biographical construction and deconstruction to which I am referring are in some sense neutral, but their actual deployment vis-à-vis male or female scientists operate with quite different consequences. In theory, the range of possibilities is open-ended, endless, and yet in practice, it is not. The processes by which science and scientists align biographically are complex, challenging and multifaceted. They are also excellent vehicles for ongoing self-reflexivity on how we write about individual lives in historical contexts. Why is it that we seem to accept Pasteur's simultaneous presence and absence in historical events, while granting the same capacity to Marie Curie, another celebrity-scientist, seems much harder?

There is hardly a village in France without a square, school, or street named after one or both of these poster children for Gallic science, but Pasteur and Curie have more than posthumous top-ten fame in common. A significant part of their consecration results also from being subjects of successful biographies authored by close relatives and being immortalized by Hollywood. Curie's biography was written by her daughter, and Pasteur's by his son-in-law (René Vallery-Radot published La Vie de Pasteur in 1900 while his father-in-law was still alive). Pasteur was played by Paul Muni in the Oscar-winning The Story of Louis Pasteur (1936) while Greer Garson starred in the MGM biopic (1943) of Eve Curie's bestseller Madame Curie (1938). 
No matter how the boundaries are drawn around the sprawling genre of biography - that runs from hagiography to metabiography, from representation as a saint to replacement by a microorganism - it offers an excellent medium through which the construction of the scientific persona, and the sexing mechanisms that continue to influence the biographical construction of the scientist both historically and in the present, can be analyzed (Bergland, 2008; Des Jardins, 2010). These sexing mechanisms are especially critical when it comes to notions of personhood, person and persona, categories not only central to the biography genre but essential components in scientists' own self-fashioning strategies and sense of self.

The purpose of this essay is to explore this liminal space by focusing on Marie Curie, whose posthumous treatment is described as oscillating between the 'dismissive and the hagiographic' (Rocqué, 1997: 276). I focus on a particular moment in the 1920s when the genre offered her - as the author of her husband's biography a unique opportunity to represent herself in the history of science. This story shows, not only how Curie explored and negotiated a range of possibilities available to her, but also our own biases, the analytical lacunas of the science biography that exist and how we might theoretically and methodologically challenge them.

\section{The science biography}

In their introduction to Telling Lives in Science: Essays on Scientific Biography, Michael Shortland and Richard Yeo (1996) describe biography as one of the most 'popular and yet least studied forms of contemporary writing' ( $p .1$ ). And while the genre's didactic potential to instruct readers in the virtues of personal example boasts a long and illustrious history, few universities offer classes or curricula in biography studies. Indeed, Nigel Hamilton (2013) claims that in academia, 'hypocrisy abounds, snobbery triumphs' (p. ii) vis-à-vis a form of writing that struggles to become fully accepted as a scholarly endeavor (see also Hamilton, 2007, 2008). 
Biographies of scientists are not that different from biographies of authors, movie stars, politicians or designers. Obviously, biographies of scientists are not automatically more 'scientific' than any other type of biography. This is why I use the term 'science biography' (Söderqvist, 1996: 45), rather than the somewhat confusing 'scientific biography'.

Telling Lives in Science (Greene, 2007) introduces some of the recurring dilemmas faced by historians of science as they wrestle with biography as 'one of the principle narrative modes in the history of science' (p. 727). While biography appears to be a format audiences find compelling, historians confront prejudices that treat the genre as an 'old-fashioned, stale and distinctly uninteresting resource' (Shortland and Yeo, 1996: xiii). The ambiguous status of the biography is understandable, if slightly incongruous. Understandable, because one can see how the genre's appeal to a broader public combined with the recognition that the science biography perpetuates a distorted picture of scientific work would cause a certain frisson among historians of science. Incongruous, because an outsider may be forgiven for asking where the history of science would be without all of its biographical emblems and narratives: from the Nobel Prize and the Davy Medal to contemporary expressions of celebrityculture of the Darwin industry (Browne, 2003) or the merchandise securing Albert Einstein a place on Forbes' annual list of top-earning dead celebrities (Pomerantz, 2013), the popular history of science seems to embrace individualization to the point of exhaustion. However, for all the residual angst about whether or not science biographies are 'about the scientist or about science' (Nye, 2006: 324), in recent years there has been a shift towards a recognition that the biography offers an 'extremely liberating genre' (Browne, 2010: 351) for the historian of science.

Overviews of the long and complex history of the science biography detail the genre's major challenges, such as the tension between representing individual and collective achievement, the question of how to overcome the fallacy of equating the history of science with the history of so-called great men and how to debunk the discovery myth once and for all (Browne, 2010; Shortland and Yeo, 1996; Söderqvist, 
2007a). If this literature does not permanently resolve such tensions, it at least provides sufficient context to reassure historians of science they no longer need be 'nervous about writing biography' (Terrall, 2006: 307).

The metabiography signals the arrival of a new representational phase. The subtitle of Nicolaas A. Rupke's (2005) biography of Alexander von Humbolt declares that it is a metabiography, and its publication marks a turning point in the visibility and credibility of the genre (Browne, 2010: 351; Livingstone, 2012: 3). The primary source material in Alexander von Humboldt is not the letters, diaries or any other conventional resource that would be foremost in the mind of a traditional biographer, but earlier Humboldt biographies. Lots of them. By sifting through layer by biographical layer Rupke deconstructs how Humboldt became Humboldt. In a review of the book for Isis, historian of science Tomas Söderqvist described the metabiography as a 'supergenre' and framed Rupke's book precisely as a biography of biographies (Söderqvist, 2007b: 203). In his reply to Söderqvist, however, Rupke appears to propose a broader metabiographical impetus, one that interprets the biographee as a composite construct of different memory cultures and so recognizes the essential instability of historical lives' (Rupke, 2008: 140).

The notion of instability is important for the arguments that follow primarily because it posits the metabiography not as a project defined by its primary source material - previous biographies of the biographee - but as an indicator of the sea change in who or what constitutes a legitimate biographical subject. Regardless of the exact contours of when and why this metabiographical shift first occurred, the history of science is now richer for a number of studies that have departed from more traditional conventions such as Mott Greene's (2007: 730-1) 'veracity', 'sequence', 'entirety' and 'verifiability', in favor of a relational approach between person and process (Biagioli, 2006; Fara, 2002; Shapin, 2008). The main protagonist no longer even needs to be human, but can be an element like radium (Rentetzi, 2008), a disease such as cancer (Mukerdjee, 2011), or some other scientific object (Daston, 2000), making the genre flexible enough to accommodate a wide spectrum of approaches 
(Renders and De Haan, 2013).

This abundance of possibilities represents a suitable juncture to return once more to The Pasteurization of France and look at how this non-biography morphed into a kind of biography anyway, thanks to its paratextual instability. Whereas the original book cover excelled in French graphic design at its least flirtatious - somber grayish cover without a trace of an image or any kind of iconographic embellishment the 2001 La Découverte paperback made some concession in terms of visual appeal. On a white cover, the publisher placed a laboratory interior with scientists going about their business, one of them possibly Pasteur himself. Not only that, it also offered a new and slightly modified title: Pasteur: Guerre et Paix des Microbes, making sure that the war and peace in question was the business of germs rather than humans.

The 1988 U.S. edition showed Pasteur in an introvert posture, looking intently at one of his vials. On the French paperback Pasteur moved about like Kutuzov, a General surveying his laboratory assistants surveying the tables, instruments, flasks and units by which they would ultimately defeat anthrax. For each new edition, we move closer to Pasteur and to a book that looks and feels more like a biography.

For some critics, The Pasteurization of France was just Latour being a closet biographer, though too caught up in his own STS prejudices to accord Pasteur his justified and prominent place in the narrative (Williams, 1999). Even so, when Latour situates his narrative in relation 'to the literary genre of sociology or social history' (Latour, 1993: 7), there seems to be at least a vague trace of the biography's affinity with literary narrative devices such as 'good story' and 'plot' (Greene, 2007: 732).

If we move from the outside of the book (increasingly packaged like a traditional biography) to its inside (looking nothing like a traditional biography), we see that Latour operates with two Pasteurs: the person (Pasteur) and the persona ('Pasteur'). A world of difference result from two little quotation marks around the name.

The importance of the second category, 'the culturally produced copy or trace of a person' (Hamilton, 2009: 11) directly relates to Pasteur's capacity to enlist the 
support and loyalty of Pasteurians, the soldiers of science whose work will consolidate the authority and power of 'Pasteur'. To enlist the Pasteurians' actions in the laboratory and their writing in journals that were both 'scientific' and 'popular', Latour does not even need Pasteur. In fact, we could argue that Latour's treatment of Pasteur in The Pasteurization of France is metabiography with a twist, because what Latour asks of us that we understand (and accept) the difference between the two Pasteurs. He does not have to ask twice. We do, because the range of possibilities by which we understand this scientist include removing him altogether. We can disassociate Pasteur from himself, we can play with him, move him about, and it does not matter. Pasteur will remain Pasteur.

It takes a certain kind of personhood to sustain being destabilized and still retain stability. Such an exercise does not apply to all persons. Indeed, from both a theoretical and methodological perspective it is interesting to ask why the science biography seems to have engaged to such a limited extent in a critical discussion of how the construction of the person might have shaped its underlying assumptions. This is particularly striking in the case of the metabiography, one might think, given its emphasis on instability and its flexibility vis-à-vis human or non-human biographees.

In the following section, I want to consider Marie Curie from Rupke's (2005) metabiographical perspective of 'composite construct'. This means approaching Curie at a particularly interesting stage in her own persona-making, when she simultaneously acted as both biographer and biographee. This line of inquiry provides new insight into Curie's construction of herself as a person and a persona, but may in extension also shed some light on how we write the 'essential instability' of scientific lives more generally. 


\section{The composite Curie(s)}

In 1920, Marie Curie agreed to write the biography of her husband Pierre for the series 'Les Grand Hommes de France'. Managing their public personas in print was something scientists were increasingly willing to do, and there appeared to be an audience hungry for such narratives (LaFollette, 1990). Precisely because Pierre Curie's work and life was so tightly bound to hers, she was now offered - through the most acceptable of forms - the possibility of overseeing her own legacy.

Fourteen years previously, on April 19, 1906, Pierre Curie was killed by a horsedrawn carriage as he was crossing the Rue Dauphine. As long as her husband was alive, Marie Curie was an irreplaceable sidekick, a collaboration-curiosity where there was never any real doubt about who led and who followed. A heavy camion, a slippery pavement, and seconds later, she was a widow with two young children to support. From enabler, shoulder of support and capable assistant, Marie Curie quickly succeeded her husband as Professor at the Sorbonne and began cementing her status as an international celebrity. In a few years, her fame far eclipsed that of her husband's. As she stepped into the limelight, he moved into her shadow. Yet as late as 1956, on the 50th anniversary of Pierre Curie's death, Marie Curie was still remembered first as 'the lonely widow,' then as 'the mother,' and only last as 'the physicist' (Laborde, 1956: 13).

Not many people today remember that Curie was her husband's biographer and fewer still can probably claim to have read Pierre Curie. In accepting the invitation to write the book, Curie was not only given an opportunity to remind the world of her husband's achievements and place him in the company of men like Descartes, Racine and Talleyrand, but to engage in legitimate self-fashioning. After all, she was her husband's scientific partner and their collaboration remain one of the most famous of all scientific partnerships (Lykness et al., 2012; Pycior, 1993; Pycior et al., 1996).

The discovery of radium and the key new term 'radioactivity' were first announced in three 'notes' in 1898 in the journal of the French Académie des sciences, 
Comptes Rendus. ${ }^{1}$ Drawing attention once more to the importance of the paratext, I want to consider very briefly how these articles operated as a form of training-ground for the Curies' authorship and authority. Throughout the three notes, Pierre Curie's identity as an author remains stable. Marie Curie's, on the other hand, is up for negotiation. Fluid, tentative and fuzzy in the contours, we see her try out different names, different authorships. The scientific claims grew stronger with each note, an assertiveness not only borne out of the evidentiary traces coming from the laboratory, but of the different authorial combinations played out in the three notes. The more radium needed to be seen as within the purview of someone's authority, the more its properties could be led into evidence, the more important was it to assign the discovery to a someone who actually could claim all of the above. In the first note, Marie Curie is a single author; next she follows after her husband, and in the third, she stands after Pierre Curie but preceding Gustave Bémont. Her names were equally flexible, beginning with Madame Sklodowska Curie, giving her full Polish name. Next up, however, Sklodowska has been abbreviated into a single letter, and she is Madame S. Curie. Finally, she ends up as Madame P. Curie, disappearing behind her husband's name. For each note, radium gets stronger and Marie Curie weaker, her authority and authorship increasingly subsumed under Pierre Curie's name.

It is worth keeping this weak/strong authorship/authority in mind when moving forward twenty years and the offer to write Pierre Curie. This time, the context is radically different. Curie is no longer beginning her career as a scientist; she is at the apex of it. While it is beyond the scope of this essay to go into the many complicated turns in the publishing history of Pierre Curie, the book was initially commissioned by the French publisher Payot, but first appeared in print in the U.S. Published by Macmillan in 1923, it was the result of Curie's highly publicized trip to the country two years previously, when her status as an international celebrity reached an alltime high. Missy Brown Meloney, editor of the women's magazine The Delineator and a huge fan of the Polish-French scientist, masterminded Curie's tours in 1921 and 1929 and wanted to translate Pierre Curie into English. More than that, she implored 
Marie Curie to tell American readers about her life as well, not only her husband's. Although Curie eventually acquiesced, the 'Autobiographical notes' only appeared in the U.S. edition of Pierre Curie and never in France. Trying to convince her of the advantages of Meloney's offer, the author Henri Pierre Roché told Curie 'if you do not tell this story yourself, it will be invented one day.' If she abdicated such future narration of her life to others, he warned, they would 'tell anecdotes' and exaggerate the 'legend' associated with her. It was a surprisingly irreverent touch that he actually put 'legend' in quotation marks. ${ }^{2}$

Pierre Curie outlined her spouse's personal qualities and followed his early achievements in painstaking detail. And while its author modestly questioned her ability to accurately depict her husband's childhood, few would have entertained the idea that this particular book could have been penned by anyone else. So when the narrative provided her with an opportunity to make a programmatic statement about how the famous husband-and-wife team viewed their work, with the benefit of hindsight and being in absolute control of the story, she made the most of it.

Our investigations had started a general scientific movement, and similar work was being undertaken in other countries. Toward these efforts Pierre Curie maintained a most disinterested and liberal attitude. With my agreement he refused to draw any material profit from our discovery. We took no copyright, and published without reserve all the results of our research, as well as the exact processes of the preparation of radium. In addition, we gave to those interested whatever information they asked of us. This was of great benefit to the radium industry, which could thus develop in full freedom, first in France, then in foreign countries, and furnish to scientists and to physicians the products which they needed. This industry still employs to-day, with scarcely any modifications, the processes indicated by us (Curie, 1923: 111).

This quote from Pierre Curie represents a biographical framing of one of the most mythological decisions made in the history of science: the decision not to patent 
radium. It is also a statement peppered with personal pronouns.

Discounting her long-standing collaboration with her daughter Irène, when Marie Curie wrote Pierre Curie she had lived and worked without her original research partner for almost twenty years. In 1923, she was more famous than Pierre Curie had ever been. Although she was commissioned to write his life, she could hardly erase herself completely when accounting for the way in which their scientific ethos of disinterestedness worked. Instead, she chose words that almost made it look as if her husband had asked her for permission to enforce the principle of nonpatenting in practice. 'With my agreement' suggests that the final disinterested word came from Marie and not Pierre Curie. But the rest is even more intriguing; 'he refused to draw any material profit from our discovery.' The vacillation regarding who was actually in control of the intellectual work produced by the couple reveals that 'he', not 'we', refused to make profit from what was 'our' discovery, their common work. Freudian slip or not, she was right in saying that only one person in this collaboration could profit or choose not to profit from their discovery, and that person was her husband.

The Code Civil at the time of the Curies' marriage did not recognize her as a legal person (Hamilton, 2009; Naffine, 1994, 2003, 2004). In fact, when the Curies were awarded the Nobel Prize in Chemistry (together with Henri Becquerel) in 1903 she was, together with all married women, children, and the insane, judged incapacité. When we look at how Curie first became a co-author and then how she narrated her story, we should remember that during the period she rose to prominence as a public figure, co-discoverer of radium, author of many scientific papers, and Nobel Prize recipient, she could not 'own' any of the intellectual property that led her to those achievements or that resulted from them. It would bestow the law with much too much power to argue that it is the great mover and shaker behind every decision Curie made, but we would be equally remiss if we did not recognize that by reserving the category of person for men only, the sexing mechanisms of the law fashioned the interpretative possibilities surrounding the authority, autonomy, and authorship that 
came with the Curies' collaboration. Crediting Marie Curie's legal status as a married woman under the Code Civil with importance means expanding the interpretative horizon whereby we consider the links between person, property, autonomy and authority in science. Marie Curie may have been the world's first female Nobel Prize recipient, but she nonetheless had few legal entitlements and was unable to sign a contract or exercise control over her own grants. During the period when Marie Curie became the public figure we think we know so well, at the time her persona begin to take shape, her formal presence in the public sphere was that of a shadow. The interstices of science, innovation, and intellectual property are historically contingent, not historically given. It would be naïve of us not to expect Curie's strategies as a scientist to develop accordingly.

The negation of patenting was so important to Curie that she returned to it, almost verbatim, in the 'Autobiographical notes'. Because she wrote directly in English this time, she may have thought long and hard about how to express herself in a foreign language, but her three typewritten drafts of the 'Autobiographical notes' are not those of an English-language novice. The ways in which Curie chooses to represent their well-known ethics are not that different in the three drafts. But finding the right words for the introductory sentence: 'My husband, as well as myself, always refused to draw from our discovery any material profit' (Curie, 1923: 225) proved altogether more difficult. She was always cautious, but when it came to ascribing agency behind the non-proprietary, disinterested stance, she was uncertain what to write. Twenty years after the fact, who had done what?

Each draft of the 'Autobiographical notes' shows Curie weighing her words carefully. In the first draft, she initially situated herself as an active participant in the events, but then changed her mind, erasing the assertive 'as well as myself'. In subsequent drafts, she toyed around with formulations that gave precedence to Pierre Curie as the instigator of the principle; she merely 'followed his view', 'shared his feeling' and 'followed his plan'. She had second thoughts about using 'our' when referring to the discovery of radium, opting first for the almost dismissive 'that', 
before reinstating the more proprietary 'our discovery' in the second draft. But in the printed version, any trace of assigning herself a role as passive bystander - sharing his feeling, following his plan - disappeared, replaced by a return to the more assertive 'as well as myself' and the definitive 'our discovery'. ${ }^{3}$ On closer inspection, Curie's preoccupation with the 'I' and the 'we' prove not that she swallowed wholesale any simple designation of autonomy and agency but that she very consciously used the biography of her husband to articulate her own role with respect to the science of radioactivity and to the 'ownership' of radium.

Framing family life as the basic unit of scientific excellence (Bergwik, 2014) may have first been set in place in Pierre Curie but it was certainly reinforced by Eve Curie in her famous biography of her mother, Madame Curie. Whereas Pierre Curie is largely forgotten, it is hardly an exaggeration to state that Madame Curie is the most important book shaping the Curie myth. Madame Curie won a National Book Award in 1937, was translated into at least twenty languages and served as the underlying work for the MGM movie with the same name. Requisite reading for anyone interested in Curie's trajectory as a person and persona, Madame Curie is not only interesting in the sense of being the bestseller/biopic that shaped so much of the public perception of Curie over the years, but also because of how it managed to find its way into the knowledge-production of science. Used as the basis for entries on Curie in dictionaries and encyclopedias, reviewed favorably in the most established of science journals, Eve Curie's biography was gradually sanctioned as a reliable account of scientific life.

In a review in Isis in 1938, George Sarton wrote that the lives of the Curies 'should be read in the same spirit as people read the lives of the saints.' Reviewing both Pierre Curie and Madame Curie at the same time for Isis, Sarton expected his Harvard and Radcliffe students to 'read and ruminate the lives of Pierre and Marie Curie; it may awaken in them, if it be there, the love of truth and the love of science' (Sarton, 1938: 484). The daughter's book on her mother, the wife's book on her husband: both texts could teach the next generation something about what a life in science should look like. Where the science biography might differ from its 
counterparts in literature, film, or the arts, however, is in its liminal existence on the border of the scientific and the non-scientific (Gieryn, 1999), and in its perhaps underrecognized ability to function as a blockade-runner between these two spheres. The biography was not just a bestselling genre or vehicle by which the memory of one or the other Curie could survive to new generations; the biography, at least in France, Marie Curie once told Missy Brown Meloney, was intended for students. ${ }^{4}$

The range of possibilities Curie explored, first when trying to find a voice and authority as a collaborator and co-author with her husband and then as his biographer, seem to prove quite emphatically 'the instability of historical lives'. We can see it in Marie Curie's complex negotiations of the 'I' and the 'we', the 'us' and the 'me' that discovered and isolated radium, strategies we can follow as the biography of her husband and her own autobiography take form (Hemmungs Wirtén, 2015: 9-13, 55-57).

\section{Sexing science biographies}

Marie Curie remains one of the most instantly recognizable faces of modern science. So far the only woman twice awarded the Nobel Prize, her 1903 and 1911 distinctions assure her a permanent seat on the Mount Olympus of science. Children read about Curie's accomplishments in school, learning just how far perseverance and commitment can take you. For each new generation, the same lesson applies: the sky is the limit, even for girls. Countless adolescents who dream about life in the laboratory consider the Polish-French scientist a role model. No textbook, dictionary, or exhaustive encyclopedia of twentieth-century science would be considered complete without her in it.

Curie's private and professional life continues to fascinate and supply steady demand for new biographies. Susan Quinn set the benchmark for the most comprehensive traditional biography to date with Marie Curie. A Life (1995), but two 
decades earlier it was Robert Reid's Marie Curie (1974) that initiated a different kind of approach, one that departed from the hagiography of Madame Curie and emotional eye-witness accounts such as Camille Marbo's [pen name for Marguerite Borel] $A$ Travers Deux Siècles (1967).

If there are different styles of doing science, there also seem to be different styles in writing science biography. Françoise Giroud's bestseller Une Femme Honorable (1981) exemplifies the French predisposition for factual-fictional narratives and more recent biographies (Gidel, 2008; Lemire, 2001; Troterau, 2011) remain steadfastly traditional in their chronological logic. Despite important contributions of a less biographical kind that have showed Curie from other perspectives (Boudia, 2000; Rocqué, 1997, 2001) and other exercises in style, such as Lauren Redniss' acclaimed book Radioactive: Marie and Pierre Curie, a Tale of Love and Fallout (2010), family-focused books such as Shelly Emling's Marie Curie and Her Daughters (2012) continue on a well-trodden path. One of Curie's biographers, Laurent Lemire (2001), has suggested that Marie Curie has fallen victim to an AngloAmerican depreciation-logic, a kind of failure on the part of the hegemonic scholarly Anglophone powers to understand that the French Do Science Differently (Lemire, 2001). Although such an argument seems grossly oversimplified, not to mention xenophobic in its own right, it does point to another important dimension of the biography: its ability to function as a vehicle for the national promotion of scientists and science (Nye, 1993).

So far, Curie has remained Curie, and it is difficult to imagine her removed from the story as Pasteur is removed, while nonetheless remaining powerfully present as 'Pasteur', from The Pasteurization of France. In some sense, it is because we understand Pasteur, microbes, war and peace as particular and generic at the same time. Particular, because while we know them to be contextually dependent on historical actors and events, we decode such particulars into universally applicable and generic categories. Exploring, embracing, and, most important of all, renouncing the male scientist's individuality and personality are all possibilities because the male 
scientist remains irreducible, complex, whole. And it is precisely because he is irreducible, complex, and whole that he can be reduced, simplified, splintered off.

Curie, on the other hand, still circulates in the closed loop reserved for a specific historical actor, whose experience as a woman is so unique that we find it almost impossible to think about it in abstracted or generalized terms. In contrast to Robert Merton's (1988: 620) list of the eponym-making giants Newton, Darwin, Freud, Einstein, Keynes or any other Great Male Scientist targeted for a narrative using The Man to get at The World, Curie remains all particular. And the impulse to demand authenticity from her (and other female scientists) is a powerful one that continues to excert influence. Not so the male scientist, who, for all his idiosyncrasies, retains his ability to function as a catalyst for generalizable observations about science. As a result, the only story Marie Curie tells is the one about her. Period. Compared to a sad Mary Poppins, labeled the Edith Piaf of radioactivity, even likened to Victor Hugo's Cosette (Lemire, 2001: 11 and 166) Curie may be malleable enough to be anyone, real or fictitious, as long as she remains one-of-a-kind.

Curie's closed-circuitry can perhaps be attributed to the ongoing promotion of her uniqueness. There is no doubt that anyone who, for whatever reason, decides to approach the 'Most Inspirational Female Scientist of All Time' (New Scientist, 2009) will have to contend with presence, rather than absence. From being heralded as the personification of European research excellence by the EU, to being a heroine for two nation-states - Poland and France - and again, thanks to her importance as a rolemodel for women in science especially: a lot of investment has gone into keeping Curie on a pedestal. But the unique position from where we seem to have such difficulty to approach Curie is less of a problem than the fact that we seem to want something from her that we do not want from Pasteur. We ask authenticity from Curie, and because we insist on having it, we make her into a female body, a body that resists being divided into Curie and 'Curie'. Two Marie Curies is a contradiction in terms. Two Louis Pasteurs is a non-issue. The demand for authenticity in combination with the preservation-logic inherent in the unique exception has worked against Curie and 
explains perhaps why there is a bit too much myth and not enough mensch in her case. Much could be gained by taking a closer look at the mechanisms that continue to place Curie on a pedestal and to broaden our understanding of her strategies of selffashioning, institution-building, networking: to understand her as the kind of modern scientist that built alliances, attracted other scientists around her and protected her investments.

\section{Conclusion}

The range of possibilities Marie Curie relied on as a biographer of her husband Pierre included a careful layering of herself and her husband's achievements, a balancing-act of documenting who had taken what decision. The textual traces around Pierre Curie show us that a lot of interest went into the production of the Curies' famous disinterestedness, and the complexity of the 'composite construct' that was Marie Curie. Any diminishing logic that situates Curie or any other female scientist as a woman first, a person only second, and a catalyst for generalizable observations on the conditions of modern science a distant third, must be resisted. One way of doing this from the perspective of the biography, meta or traditional, is to further engage with the category of the person. An odd suggestion, perhaps, given that the person for such a long time has stood at the center of the biographical project. And yet, personhood is a much more troubled category than we generally think.

When I offered Pasteurization as a term helping us think about the biographical range of possibilities I wanted these to include our epistemological choices. Ultimately, self-reflexivity about what we do when we write about scientists theoretically, methodologically, epistemologically - may in some sense be a productive way of resisting the sexing mechanisms in the science biography and move towards a more inclusive understanding of how 'the instability of historical lives' is produced. 


\section{Notes}

The Fonds Curie or the Curie archives at the Bibliothéque National are abbreviated as NAF (Nouvelles acquisitions françaises) côte 18365-18517. References in the endnotes follow the format of NAF 18450, followed by the letter $\mathrm{f}$. (for 'feuille') indicating the page number within a particular côte.

1. Mme Sklodowska Curie, 'Rayons émis pas les composés de l'uranium et du thorium,' Comptes Rendus 126 (1898): 1101-03. M. P. Curie et de Mme S. Curie, 'Sur une substance nouvelle radio-active, contenue dans la pechblende,' Comptes Rendus 127 (1898), 175-78. M. P. Curie, de Mme P. Curie et de M. G. Bémont, 'Sur une nouvelle substance fortement radio-active, contenue dans la pechblende,' Comptes Rendus 127 (1898): 1215-17.

2. NAF 18457, letter from Henri Pierre Roché to Marie Curie, May 21, 1920, f. 4-8.

3. NAF 18383, f. 139, 174, 213-14.

4. NAF 18457, letter from Marie Curie to Missy Brown Meloney, May 20, 1922, f. 112. 


\section{References}

Bergland RL (2008) Maria Mitchell and the Sexing of Science: An Astronomer Among the American Romantics. Boston, MA: Beacon Press.

Bergwik S (2014) An assembled affinity of science and home: The gendered lifestyle of Svante Arrhenius and early twentieth century physical chemistry. Isis 105(2): 265291.

Biagioli M (2006) Galileo's Instruments of Credit: Telescopes, Images, Secrecy. Chicago, IL: University of Chicago Press.

Boudia S (2001) Marie Curie et son laboratoire: Sciences et industrie de la radioactivité en France. Paris: Editions des archives contemporaines.

Browne J (2010) Making Darwin: Biography and the changing representations of Charles Darwin. Journal of Interdisciplinary History 40(3): 347-373.

Browne J (2009) Looking at Darwin: Portraits and the making of an icon. Isis 3: 54270.

Browne J (2003) Charles Darwin as a celebrity. Science in Context 1/2: 175-194.

Curie E (1938) Madame Curie. Paris: Gallimard.

Curie M (1924) Pierre Curie. Paris: Payot.

Curie M (1923) Pierre Curie and 'autobiographical notes.' NewYork: Macmillan.

Daston L (2000) Biographies of Scientific Objects. Chicago, IL: University of Chicago Press.

Des Jardins L (2010) The Madame Curie Complex: The Hidden History of Women in Science. New York: The Feminist Press. 
Emling S (2012) Marie Curie and Her Daughters. New York: Palgrave Macmillan.

Fara P (2002) Newton: The Making of Genius. New York: Columbia University Press.

Genette G (1987) Seuils. Paris: Points.

Gidel H (2008) Marie Curie. Paris: Flammarion.

Gieryn T (1999) Cultural Boundaries of Science: Credibility on the Line. Chicago, IL: University of Chicago Press.

Giroud F (1981) Une Femme Honorable. Paris: Fayard.

Greene MT (2007) Writing scientific biography. Journal of the History of Biology 4: 727-59.

Hamilton N (2007) Biography: A Brief History. Cambridge, MA: Harvard University Press.

Hamilton N (2008) Biography. A Primer. Cambridge, MA: Harvard University Press.

Hamilton N (2013) Foreword. In: Renders H and De Haan B (eds) Theoretical

Discussions of Biography: Approaches from History, Microhistory, and Life Writing.

Lewiston, NY: Edwin Mellen Press, i-v.

Hamilton S (2009) Impersonations: Troubling the Person in Law and Culture. Toronto, ON: University of Toronto Press.

Hemmungs Wirtén E (2015) Making Marie Curie: Intellectual Property and Celebrity Culture in an Age of Information. Chicago, IL: University of Chicago Press.

LaFollette M (1990) Making Science our Own: Public Images of Science, 1910- 1955. Chicago, IL: University of Chicago Press.

Laborde A (1956) Pierre Curie dans son laboratoire. In: Conférence aite au Palais de la 
Découverte à l'occasion du 50e anniversaire de la mort de Pierre Curie. Paris: Les Conférences du Palais de la Découverte.

Latour B (1984) Les Microbes: Guerre et Paix. Paris: Metaillie.

Latour B (1988) The Pasteurization of France. Alan Sheridan and John Law (trans). Cambridge, MA: Harvard University Press.

Latour B (2001) Pasteur: Guerre et Paix des Microbes. Paris: La Découverte.

Lemire L (2001) Marie Curie. Paris: Perrin.

Livingston J D (2012) A 'body' of evidence: The posthumous presentation of David Livingstone. Victorian Literature and Culture 40: 1-24.

Lykknes A, Opitz DL and Van Tiggelen B (eds) (2012) For Better or For Worse?

Collaborative Couples in the Sciences. Basel: Springer.

Marbo C [Marguerite Borel] (1967) A Travers Deux Siècles. Souvenirs et Rencontres (1883-1967). Paris: Grasset.

Merton R (1988) The Matthew effect in science, II: Cumulative advantage and the symbolism of intellectual property. Isis 4: 606-623.

Mukerdjee S (2010) The Emperor of all Maladies: A Biography of Cancer. New York: Simon \& Schuster.

Naffine N (1994) The legal structure of self-ownership: Or the self-possessed man and the woman possessed. Journal of Law and Society 25(2): 193-212.

Naffine N (2004) Our legal lives as men, women and persons. Legal Studies 24: 621642.

Naffine N (2003) Who are law's persons? From Cheshire cats to responsible subjects. 
The Modern Law Review 3: 346-367.

New Scientist (2009) Marie Curie tops poll of most inspirational women in science. Available at: http://www.unesco.org.uk/uploads/PR-PollofWomeninScience1July2009.pdf. (accessed 30 January 2015).

Le Nouvel Observateur (2005) De Gaulle plus grand Français de tous le temps. April 6, Available at: http://tempsreel.nouvelobs.com/culture/20050405.0BS3037/degaulle-plus-grand-francaisde-tous-les-temps.html. (accessed 30 January 2015).

Nye MJ (1993) National styles? French and English chemistry in the nineteenth and early twentieth centuries. Osiris 8: 30-49.

Nye MJ (2006) Scientific biography: History of science by another means? Isis 97(2): 322-29.

Pomerantz D (2013) Michael Jackson leads our list of the top-earning dead celebrities. Forbes, 23 October 2013.

Pycior HM, Slack NG and Abir-Am PG (eds) (1996) Creative Couples in the Sciences. New Brunswick, NJ: Rutgers University Press.

Pycior HM (1993) Reaping the benefits of collaboration while avoiding its pitfalls: Marie Curie's rise to scientific prominence. Social Studies of Science 3: 301-323 Reid R (1974) Marie Curie. London: Collins.

Renders H and De Haan B (2013) Theoretical Discussions of Biography: Approaches from History, Microhistory, and Life Writing. Lewiston, NY: Edwin Mellen Press.

Rentetzi M (2008) Trafficking Materials and Gendered Experimental Practices: Radium Research in Early 20th Century Vienna. New York: Columbia University Press.

Rheingold N (1991) Review of The Pasteurization of France by Bruno Latour. 
Technology and Culture 32(1): 177-79.

Rocqué X (1997) Marie Curie and the radium industry: A preliminary sketch. History and Technology 4: 267-91.

Rocqué X (2001) Displacing radioactivity. In: Joerges B and Shinn T (eds)

Instrumentation: Between Science, State and Industry. Amsterdam: Kluwer, 51-68

Rupke NA (2008) Letter to the editor. Isis 99(1): 140.

Rupke NA (2005) Alexander von Humboldt: A Metabiography. Chicago, IL: University of Chicago Press.

Sarton G (1938) Review of Madame Curie, Pierre Curie and Marie Sklodowska-Curie, 1867-1934 by Claudius Regaud. Isis 2: 480-484.

Shapin S (2008) The Scientific Life: A Moral History of a Late Modern Vocation. Chicago,

IL: University of Chicago Press.

Shortland M and Yeo R (1996) Telling Lives in Science: Essays on Scientific Biography. Cambridge: Cambridge University Press.

Söderqvist T (2007a) History and Poetics of Scientific Biography. Aldershot, UK: Ashgate.

Söderqvist T (2007b) Review of Nicolaas A. Rupke, Alexander von Humboldt: A Metabiography, Isis 98(1): 203-04.

Söderqvist T (1996) Existential projects and existential choice in science: Science biography as an edifying genre. In: Shortland M and Yeo R, Telling Lives in Science: Essays on Scientific Biography. Cambridge: Cambridge University Press.

Terrall M (2006) Biography as cultural history of science. Isis 97(2): 306-313. 
Troterau J (2011) Marie Curie. Paris: Gallimard.

Vallery-Radot R (1900) La vie de Pasteur. Paris: Librarie Hachette.

Williams (1999) The life of scientists. Physis 8: 199-21.

\section{Author biography}

Eva Hemmungs Wirtén is Professor of Mediated Culture in the Culture Studies Tema of the Department of Social Change and Culture at Linköping University, Sweden. Her research has mainly focused on the cultural significance of intellectual property and the public domain, topics she explored in No Trespassing: Authorship, Intellectual Property and the Boundaries of Globalization (2004) and Terms of Use: Negotiating the Jungle of the Intellectual Commons (2008). Her most recent book is Making Marie Curie: Intellectual Property and Celebrity Culture in an Age of Information (Chicago, IL: University of Chicago Press, 2015). 